Gas-chromatographic studies of the urinary androgenic steroids were performed and their significance has been considered:

We should like to thank Dr. J. G. Burger for permission to publish this article; Drs. H. Brown, H. Webb, and P. J. M. Retief for referring cases ; Professor C. J. Uys for help with interpretation of the histological preparations; Dr. M. Modlin for testicular biopsies; and Dr. L. C. Isaacson and the staff of the Endocrine Research Laboratories for special investigations.

This work is supported by the South African Council for Scientific and Industrial Research in grants to the Endocrine Research Group, and by grants from the Staff Research Fund of the University of Capetown.

\section{REFERENCES}

Acheson, R. M., and Smith, H. V. (1958). Quart. F. Med., 27, 83. Allimant, H., and Peiffert, G. (1952). Presse méd., 60, 1390.

Appleby, J. I., Gibson, G., Norymberski, J. K., and Stubbs, R. D. (1955). Biochem. F., 60, 453 .

Babinski, M. J. (1900). Rev. neurol., 8, 531.

Bar-Sela, M. E and Critchlow, V. (1962). "Delayed Puberty Following Electrical Stimulation of Amygdala in Female Rats." Presented at 44th Annual Meeting of Endocrine Society, Chicago, III, 22 June. 44th Annual Meeting of Endocrine Society,

Bauer, H. G. (1954). F. clin.
Brit. med. F., 1964, 2, 584 .

Cleghorn, R. A., Hyland, H. H., Mills, J. R. F., and Linell, E. A. (1938). Quart. F. Med., 7, 183.

Dekanski, J. (1949). Brit. f. exp. Path., 30, 272.

Donovan, B. T., and van der Werff ten Bosch, J. J. (1959). F. Physiol. (Lond.), 147, 78

Dorfman, R. I, Forchielli, E., and Gut, M. (1963). Recent Progr. Hormone Res., $19,251$.

and Shipley, R. A. (1956). The Androgens. Chapman and Hall, London.

Eaves, E. C., and Croll, M. M. (1930). Brain, 53, 56.
Elwers, M., and Critchlow, V. (1960). Amer. F. Physiol., 198, 381.

Ford, F. R., and Guild, H. (1937). Bull. Fohns Hopk. Hosp., 60, 192.

Fröhlich, A. (1901). Wien, klin. Rdsch. $15,883$.

Greulich, W. W., and Pyle, S. I. (1959). Radiographic Atlas of Skeletal Development of the Hand and Wrist, 2nd ed. Oxford University Press, London.

Hamburger, C. (1948). Acta endocr. (Kbh.), 1, 19.

Hay, D. R. (1960). Brit. med. F., 1, 707.

Heikel, P., and Wasz-Höckert, O. (1963). Acta paediat. (Uppsala), Suppl. No. 141, p. 88.

Horowitz, S., and van der Werff ten Bosch, J. J. (1962). Acta endocr. (Kbh.), 41, 301 .

Johnsen, S. G. (1956a). Ibid., 21, 146.

(1956b). Ibid., 21, 157.

Kahana, L., Lebovitz, H., Lusk, W., McPherson, H. T., Davidson, E. T. Oppenheimer, J. H., Engel, F. L., Woodhall, B., and Odom, G. (1962). F. clin. Endocr., 22, 304.

Lewis, B., and Stewart, F. (1962). S. Afr. F. Lab. clin. Med., 8, 160.

Lincoln, E. M., Sordillo, S. V. R., and Davies, P. A. (1960). Ұ. Paediat., $57,807$.

Lorber, J. (1951). Proc. roy. Soc. Med., 44, 726.

- (1952). Arch. Dis. Childh., 27, 542. (1958a). Ibid., 33, 315

- (1958b). Amer. Rev. Tuberc., 78, 38

Lorenz, E. (1959). Neue öst. Z. Kinderheilk, 4, 105.

Medical Research Council Committee on Clinical Endocrinology (1951). Lancet, 2, 585.

Nelson, W. E. (1959). Textbook of Pediatrics, 7th ed. Saunders, Phila-

delphia.
Peruzzi, P. F. (1958). Riv. Clin. pediat., 62, 390.

Peruzzi, P. F. (1958). Riv. Clin. pediat., 62, 390.

Reichlin, S. (1963). New Engl. F. Med., 269, 1246.
Richter, R. B. (1951). f. Neuropath. exp. Neurol., 10, 368.

Seckel, H. P. G. (1946). Med. Clin. N. Amer., 30, 183. Scott, W. W., and Benditt, E. P. (1949). Amer. F. Dis. Child., 78, 484.

Todd, R M., and Neville, J. G. (1964). Arch. Dis. Childh., 39, 213.

Van de Wiele, R. L., and Lieberman, S. (1960). In Biological Activities of Sterozds in Relation to Cancer, edited by G. Pincus and E. P. Vollmer, p. 93. Academic Press, New York.

Wasz-Höckert, O., and Donner, M. (1963). Acta paediat. (Uppsala), Suppl. No. 141 , p. 26.

Weinberger, L. M., and Grant, F. C. (1941). Arch. intern. Med., 67, 762 . sity of Bristol at Bristol Royal Infirmary.

+ Lecturer in Medicine, Department of Medicine, University of Bristol at

Bristol Royal Infirmary.
$\ddagger$ General Practitioner, Portishead, Somerset.

$\$$ Dietitian, Department of Medicine, University of Bristol at Bristol Royal Infirmary. conducted during 1962-3, when 51 patients were seen. These were compared with a similar group of aged control subjects who were without apparent evidence of underlying disease. These patients were in the National Health practice of one of us (J. L. P.), and all volunteered for the study. The practice in question contains a fairly high percentage of retired elderly middle-class patients.

\section{Patients Studied}

Fifty-one consecutive patients were seen on arrival at the municipal home. Their ages ranged from 59 to 95 , and 45 were 70 years and over. There were 17 men and 34 women. Two patients over 70 years old were uncertain of their exact age. A full clinical examination of the patients was performed, including a rectal examination. The weight was recorded and portable chest radiographs were also taken. An inquiry into each patient's financial, social, and nutritional background was made. If clinical and radiological examination showed no evidence of organic disease likely to cause folic-acid deficiency, the following tests were performed.

1. After $15 \mathrm{~g}$. of oral L-histidine the urine was examined for formiminoglutamic acid (Figlu), using electrophoresis on cellulose acetate (Kohn et al., 1961). Excretion of Figlu was estimated by 
visual inspection of spots and expressed at $0,+,++$, or +++ . $\mathrm{A}+t+$ spots represents excretion of $>500 \mathrm{~kg} . / \mathrm{ml}$. of urine.

2. Haemoglobin, packed cell volume, and white-cell count were measured (Dacie, 1956).

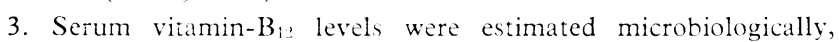
Lactobacillus lichmannii (normal 140-900 $\mu . \mathrm{g} . / \mathrm{ml}$.) being used.

4. Serum folate levels were estimated microbiologically, L. casei (normal level $5.9-21 \mathrm{~m} " \mathrm{~g} . / \mathrm{ml}$.) being used.

5. In some patients vitamin-C levels were estimated by the method of Roe and Kuether (1943) but using the buffy coat of blood samples. This estimation correlates well with clinical evidence of deficiency.

6. In certain patients folic-acid-clearance tests were performed as described by Chanarin et al. (1958).

7. Dietary intake of folic acid, ascorbic acid, iron, vitamin $B_{12}$, protein, and total calories of patients and control subjects was assessed, and figures for these were calculated (McCance and Widdowson, 1960).

These procedures having been carried out, the patients were not seen for a further six months, when clinical examination, reweighing, and special tests were repeated. Patients who had died or obviously deteriorated during this period of time or who were ill were excluded from the series in order that changes in nutrition could be attributed to the duration of stay at the home. There were five deaths, and four other patients were clearly deteriorating - two from unknown causes and two with neoplastic disease. There were also two discharges, so that after initial acceptance 11 patients could not be further studied for these reasons.

Clinical Examination.-Of the 51 patients initially examined clinical evidence of anaemia was confirmed in six, the haemoglobin in each case being $70 \%$ or less. These patients were excluded from the survey, as they had an established anaemia of some degree on arrival at the home. Of these six patients the anaemia was due to iron-deficiency following gastrectomy in two, to undiagnosed pernicious anaemia in two, to rheumatoid arthritis in one, and to nutritional folic-acid deficiency in one (this case is separately reported below). Fiftcen patients were described as "wasted" (weight $<7$ stone; $44.5 \mathrm{~kg}$., and eight were mentally confused. Apart from wasting, mental confusion, and senility, the condition of all the other patients was considered to be fair, though some had conditions common in the elderly, such as Parkinsonism, Paget's discase, and mild congestive heart failure, and three patients had an atrophic sore tongue-two of the latter had megaloblastic anaemia (one had pernicious amaemia and one was folic-acid-deficient), the third had a low serum folate and excreted a marked excess of Figlu. With the previous 11 exclusions and the six associated with anaemia, 17 were therefore excluded, so that 34 patients could be followed.

Social Aspects.-It must be obvious that the entrants to a municipal home are likely to be those without friends or relatives or whose presence could not be further tolerated by their families. Many of our pationts lived alone or with aged relatives who were equally inable to look after themselves. Death or illness of a partner or relative was a common cause for admission. Confirmatory evidence of poor living conditions and of a disinclination to look after themselves was apparent in our patients. They rarely went out and personal hygiene was often poor. The majority were existing on an oldage pension alone ( $2214 \mathrm{~s}$. a week, only $10 \%$, had applied for National Assistance, and only two had a pension from other sources.

\section{Results}

\section{Haemoglobin Levels}

Haemoglobin levels (Fig. 1 in the patients (excluding the six who had clinical anaemia) are contrasted with those in our control subjects. It will be seen that, even allowing for exclusion of these six patients, there is a significant reduction of haemoglobin levels in the remainder, so that eight others (three men and five women) had haemoglobin levels less than $80 \%$. The differences between male patients and controls is significant $(t=5.59 ; \mathrm{P}<0.0001)$, but there is no significant difference between female patients and controls.

After at least six months' stay in the home eight of the patients (34) considered suitable for inclusion in the survey showed a rise in haemoglobin $(>5 \%$ ) (five without iron therapy). In six of the eight patients the initial values were less than $80 \%$. In two patients haemoglobin levels remained unchanged (less than $80 \%$ ). In three patients with normal haemoglobin levels on admission there was a fall to less than $80^{\circ}$, after six months-one of these having developed a bleeding gastric carcinoma, and two others developing anaemia without apparent cause. These three subjects were excluded from the follow-up series.

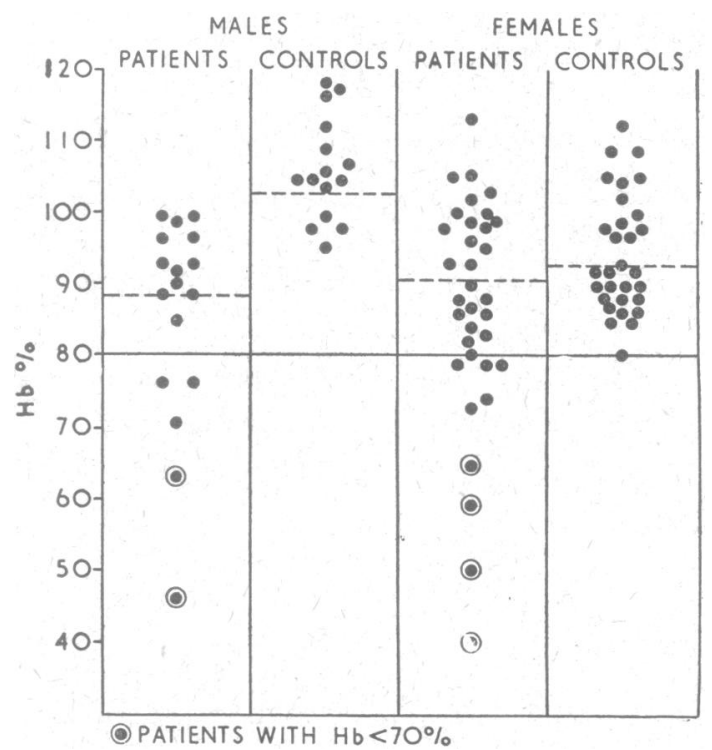

FIG. 1.-Haemoglobin levels in patients and controls. Dotted lines indicate mean values.

\section{Serum Folate Levels}

In 50 of the 51 patients folate levels (Fig. 2) were measured and were found to be below $6 \mathrm{~m} \mu \mathrm{g}$. in 40 and below $3 \mathrm{~m} \mu \mathrm{g}$. in

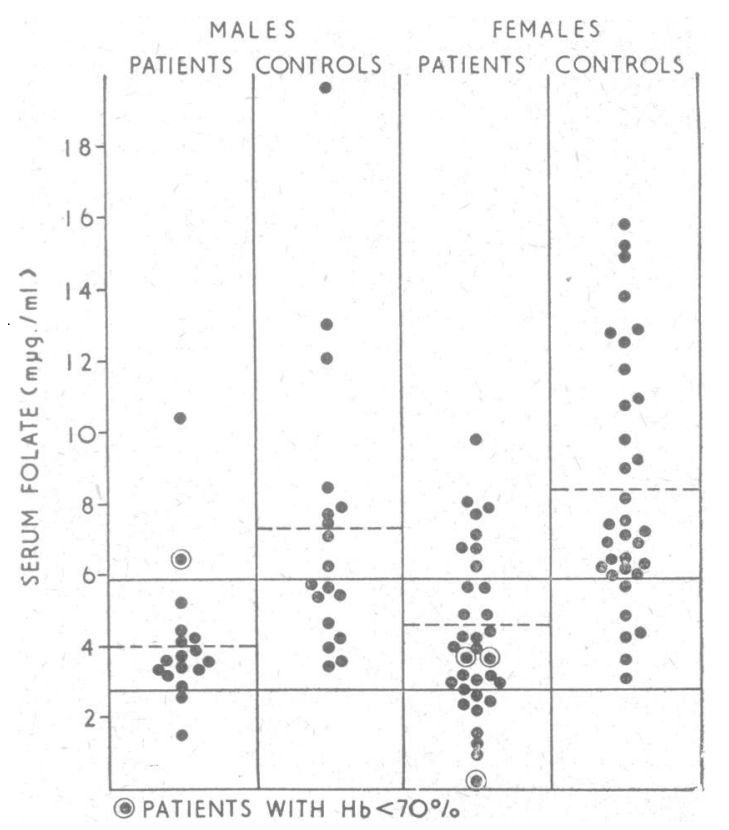

FIG. 2.-Serum folate levels in patients and controls. Dotted lines 
10. Only 10 patients had levels in the accepted normal range (6-21 $\mathrm{m} \mu \mathrm{g} . / \mathrm{ml}$.). In the six excluded anaemic patients folate levels ranged from 0.1 to $6.5 \mathrm{~m} \mu \mathrm{g}$., the lowest being in a patient with nutritional folic-acid deficiency, whose case is recorded below. Of the 10 patients with folate levels below $3 \mathrm{~m} \mu \mathrm{g}$. all but two had normal haemoglobin levels. No control subjects had folate levels less than $3 \mathrm{~m} \mu \mathrm{g}$., but in 15 controls the level ranged from 3 to $6 \mathrm{~m} \mu \mathrm{g}$. $/ \mathrm{ml}$. There was a significantly lower serum folate level in both male and female patients compared with the controls (males $\mathrm{t}=2.91, \mathrm{P}<0.01$; female $\mathrm{t}=5.26$, $\mathbf{P}<0.001)$. There was also a significantly greater scatter of folate values in controls than in patients.

After a stay in the home there was a rise of serum folate levels in only seven of the 23 patients with subnormal levels who could be followed; in each case the level rose to normal (>6 m $\mu \mathrm{g} . / \mathrm{ml}$.). In none of the eight patients with very low levels did a rise to the normal level occur. It is significant that two patients with very low folate levels were clearly deteriorating when seen on the second occasion and had already been excluded from the follow-up.

\section{Figlu Excretion}

Figlu excretion (Fig. 3) after histidine-loading was satisfactorily completed in 50 patients, and in 31 of them the amounts excreted were in excess. Four of six excluded patients with severe anaemia excreted Figlu. Of the remaining 25 seven of eight with $\mathrm{a}+++$ Figlu excretion had folate levels below $6 \mathrm{~m} \mu \mathrm{g} . / \mathrm{ml}$. There was, however, no close relation betwcen less marked Figlu excretion and serum folate levels-positive Figlu excretion $(t$ or ++ ) occurring in three patients with normal folate levels, and negative Figlu excretion occurring in 12 patients with serum folate levels less than $6 \mathrm{~m} \mu \mathrm{g} . / \mathrm{ml}$. Fifteen control subjects excreted Figlu, only one showing a greater than $(+)$ excretion.

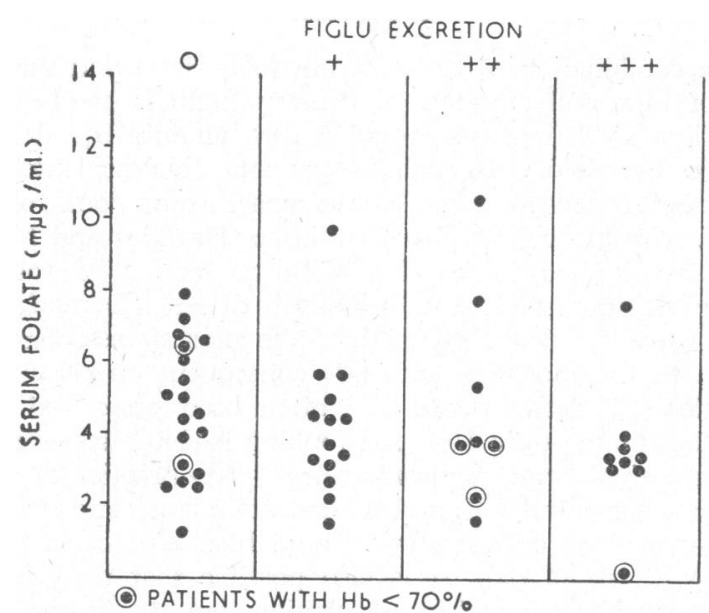

FIG. 3.-Figlu excretion in relation to serum folate levels in 50 patients.

Figlu excretion returned to normal in 17 of the 23 patients who were followed for six months; it remained elevated and unchanged in four and increased in two others. Eight patients excreting excess Figlu died, deteriorated, or were discharged.

Of the 17 patients whose Figlu excretion decreased there was an increase in serum folate level of $1 \mathrm{~m} \mu \mathrm{g}$. or more in eight, in six it was unchanged (three of these six having levels in normal range), and in three it fell. In the three patients whose folate level fell despite the disappearance of Figlu, there was no apparent clinical change or deterioration. Only four patients excreted more Figlu after a six-month stay in the home than they did on admission, and in two of these the folate level was still low $(3.0$ and $4.1 \mathrm{~m} \mu \mathrm{g}$.) on re-estimation. In the third the folate level was normal and remained un- changed. The fourth patient had a very low serum folate level $(1.4 \mathrm{~m} \mu \mathrm{g} . / \mathrm{ml}$.) which remained unchanged, the patient dying shortly after the second examination.

\section{Vitamin-B $\mathbf{B}_{12}$ Levels}

Vitamin- $B_{1: 2}$ levels were measured in 48 patients. There was no significant difference between serum vitamin- $\mathrm{B}_{12}$ levels in male patients and controls, but some difference was seen in the female patients and female controls, the patients having a lower level $(t=3.33, P<0.005)$. Two female patients with pernicious anaemia were not included in these results, but five other patients, four of them females, had levels less than $140 \mu \mu . / \mathrm{ml}$. None of these five patients was anaemic.

\section{Vitamin-C Levels}

In eight patients vitamin-C levels ranged from 6.3 to 14.7 mg./100 g. (Table I). In each of these the serum folate was less than $6 \mathrm{~m} \mu \mathrm{g}$., and four of them excreted Figlu $(+$ or ++ ). There was no clinical evidence of scurvy. Vitamin-C levels were remeasured in the eight patients after a six-month stay in the home, and in all but one of the seven with the lowest levels it increased, the increase ranging from 1.1 to 8.4 mg./100 g. These patients were all apparently well. A rise in vitamin-C level was not seen in one patient with a low level, who was obviously deteriorating (Case 5, Table 1), and in the patient with the highest level (Case 8).

\begin{tabular}{|c|c|c|c|c|c|}
\hline \multirow{2}{*}{ No. } & \multirow{2}{*}{\multicolumn{2}{|c|}{$\begin{array}{c}\text { 1st Vit. C } \\
\text { (mg./100 g.) }\end{array}$}} & \multirow{2}{*}{$\begin{array}{l}\text { Serum Folic- } \\
\text { acid Level } \\
(\mathrm{m} \mu \mathrm{g} . / \mathrm{ml} .)\end{array}$} & \multicolumn{2}{|c|}{ Folic-acid Clearance } \\
\hline & & & & $3 \mathrm{~min}$. & $30 \mathrm{~min}$. \\
\hline $\begin{array}{l}1 \\
2 \\
3 \\
4 \\
5 \\
6 \\
7 \\
8\end{array}$ & $\begin{array}{r}9 \cdot 2 \\
6 \cdot 3 \\
7 \cdot 0 \\
9 \cdot 1 \\
7 \cdot 1 \\
9 \cdot 6 \\
6 \cdot 6 \\
14 \cdot 7\end{array}$ & $\begin{array}{c}13 \\
10 \\
9 \cdot 9 \\
14 \cdot 3 \\
7 \cdot 2 \\
18 \\
7 \cdot 7 \\
14 \cdot 0\end{array}$ & $\begin{array}{l}4 \cdot 5 \\
3 \cdot 4 \\
5 \cdot 1 \\
5 \cdot 4 \\
4 \cdot 3 \\
3 \cdot 8 \\
4 \cdot 1 \\
4 \cdot 4\end{array}$ & $\begin{array}{l}\overline{160} \\
\overline{142} \\
\overline{108} \\
96 \\
115\end{array}$ & $\begin{array}{l}\frac{30}{10} \\
47 \cdot 7 \\
8 \overline{2} \\
21 \\
29\end{array}$ \\
\hline
\end{tabular}

\section{Folic-Acid Clearance}

Folate clearance tests (Table I) were performed in five patients. In all of these the initial serum folate levels were between 3.4 and $5.4 \mathrm{~m} \mu \mathrm{g}$. $/ \mathrm{ml}$., and only one patient was excreting Figlu. In each case the 3-minute and the 30-minute figures were in the normal range.

\section{Diet and Weight}

At the best a dietary history can give only a rough indication of nutritional status, and in the elderly patient further inaccuracies must arise. However, by including patients who could give a reasonable account of their food intake, and excluding those who were ill, confused, or forgetful, some useful information was obtained.

Dietary histories were obtained from 31 entrants to the home and from 35 elderly controls ( $>70$ years of age). It will be seen (Table II) that there was a significant difference between these groups with respect to folic-acid, iron, protein, and total calorie intake.

With respect to total calories, six patients (two males and four females) were existing on diets containing less than 1,000 calories a day, and a further six (two males and four females): were taking between 1,000 and 1,200 calories a day. Only one of our controls was having less than 1,200 calories. Certain points concerning diets of individual patients are worthy of 
note, as they indicate the type of problem encountered. Thus one elderly woman fed her cats on more expensive fish than she bought for herself, while an elderly man begged scraps from his neighbours and yet kept and fed 13 cats in a filthy squalid flat. Other patients living with their children declared that they existed on scraps left over after their grandchildren had eaten, though these accusations may have been due to paranoid delusions. On the credit side several elderly men were keen gardeners and produced a constant supply of fresh vegetables.

\begin{tabular}{|c|c|c|c|c|c|}
\hline & & \multicolumn{2}{|c|}{ Males } & \multicolumn{2}{|c|}{ Females } \\
\hline & & $\begin{array}{l}\text { Patients } \\
\text { (11) }\end{array}$ & $\begin{array}{l}\text { Controls } \\
\text { (11) }\end{array}$ & $\begin{array}{l}\text { Patients } \\
\text { (20) }\end{array}$ & $\begin{array}{l}\text { Controls } \\
\text { (24) }\end{array}$ \\
\hline $\begin{array}{l}\text { Folic acid } \\
(\mu \mathrm{g} . / \text { day })\end{array}$ & $\left\{\begin{array}{l}\text { Mean } \\
\text { S.D. . . }\end{array}\right.$ & $\begin{array}{l}31.3 \\
\pm 18.5 \\
t=3.53\end{array}$ & $\begin{array}{r}52.6 \\
\pm 7.5 \\
P<0.01\end{array}$ & $\begin{array}{l}33 \cdot 2 \\
\pm 3 \cdot 5 \\
t=5 \cdot 10\end{array}$ & $\begin{array}{r}52.7 \\
\pm 11.9 \\
P<0.001\end{array}$ \\
\hline $\begin{array}{l}\text { Ascorbic acid } \\
\text { (mg./day) }\end{array}$ & $\left\{\begin{array}{l}\text { Mean } \log \text { value } \\
\text { S.D. .. }\end{array}\right.$ & $\begin{array}{c}1.308 \\
\pm 0.225 \\
t=0.73\end{array}$ & $\begin{array}{c}1.378 \\
\pm 0.221 \\
\mathrm{P}=\text { Not sig. }\end{array}$ & $\begin{array}{c}1.146 \\
\pm 0.271 \\
t=3.32\end{array}$ & $\mid \begin{array}{c}1.372 \\
\pm 0.151 \\
P<0.01\end{array}$ \\
\hline Iron (mg./day) & $\left\{\begin{array}{l}\text { Mean } \\
\text { S.D. . . }\end{array}\right.$ & $\begin{array}{l}6.38 \\
\pm 2.51 \\
t=2.87\end{array}$ & $\mid \begin{array}{c}9.33 \\
\pm 2.31 \\
P<0.01\end{array}$ & $\begin{array}{c}6.64 \\
+2.64 \\
t=3.09\end{array}$ & $\mid \begin{array}{c}9.10 \\
\pm 0.151 \\
P<0.01\end{array}$ \\
\hline Protein (g./day) & $\left\{\begin{array}{l}\text { Mean } \log \text { value } \\
\text { S.D. } . .\end{array}\right.$ & $\begin{array}{c}1.643 \\
\pm 0.164 \\
t=4 \cdot 18\end{array}$ & $\begin{array}{c}1.865 \\
\pm 0.063 \\
P<0.001\end{array}$ & $\begin{array}{c}1.630 \\
\pm 0.147 \\
t=4.39\end{array}$ & $\begin{array}{c}1.785 \\
\pm 0.089 \\
P<0.001\end{array}$ \\
\hline Calories/day & $\left\{\begin{array}{l}\text { Mean } \\
\text { S.D. . . }\end{array}\right.$ & $\begin{array}{l}1,295 \\
\pm 364 \\
t=5.45\end{array}$ & $\begin{array}{r}2,234 \\
\pm 441 \\
\mathrm{P}<0.001\end{array}$ & $\begin{array}{l}1,357 \\
\pm 419 \\
\mathrm{t}=4 \cdot 45\end{array}$ & $\begin{array}{r}1,867 \\
\pm 341 \\
P<0.001\end{array}$ \\
\hline
\end{tabular}

* Log values have been used in respect of ascorbic acid and protein in order to normalize the distribution.

The diet given to the inmates at the home was analysed; it will be seen that with moderate helpings a diet containing adequate intake of the various foodstuffs (Table III) was provided. Further, it is likely that additions bought from pocket-money or given by visiting relatives were made. A rough note of each patient's food intake was provided by the staff when the patient attended the second clinical examination, and all but seven were found to be eating well. This accorded well with the gain in weight commonly noted. Of the 34 subjects who were followed, a gain in weight of $>4 \mathrm{lb}$. (1.8 kg.) (and not due to fluid retention) occurred in 20 , and in seven (Fig. 4) this was $10 \mathrm{lb}$. (4.5 kg.) or over. Only five patients lost weight-four less than $4 \mathrm{lb}$. (1.8 kg.), though loss of weight was common in those deteriorating and not included in the survey.

Table III.-Calculated Average Daily Dietary Intake of Patients Over a Four-week Period

\begin{tabular}{|c|c|c|c|c|c|c|}
\hline & \multicolumn{6}{|c|}{ Average Daily Intake } \\
\hline & $\begin{array}{l}\text { As. Acid } \\
\text { mg. }\end{array}$ & $\begin{array}{l}\mathrm{B}_{12} \\
\mu \mathrm{g} .\end{array}$ & $\left|\begin{array}{c}\text { Folic Acid } \\
\mathrm{\mu g} .\end{array}\right|$ & $\begin{array}{l}\mathrm{Fe} \\
\mathrm{mg} .\end{array}$ & $\begin{array}{c}\text { Protein } \\
\text { g. }\end{array}$ & $\begin{array}{l}\text { Total } \\
\text { Cails. }\end{array}$ \\
\hline $\begin{array}{l}\text { Week I } \\
\text { Week II } \\
\text { Week III } \\
\text { Wcek IV }\end{array}$ & $\begin{array}{l}13 \\
19 \\
12 \\
11\end{array}$ & $\begin{array}{l}2 \cdot 9 \\
5 \cdot 7 \\
2 \cdot 9 \\
2 \cdot 9\end{array}$ & $\begin{array}{l}46 \cdot 3 \\
62 \cdot 9 \\
46 \cdot 3 \\
44 \cdot 8\end{array}$ & $\begin{array}{r}5 \cdot 3 \\
12 \cdot 2 \\
5 \cdot 8 \\
5 \cdot 7\end{array}$ & $\begin{array}{l}52 \cdot 3 \\
52 \cdot 6 \\
52 \cdot 2 \\
50 \cdot 6\end{array}$ & $\begin{array}{l}1,559 \\
1,579 \\
1,707 \\
1,627\end{array}$ \\
\hline Average & $13 \cdot 75$ & $3 \cdot 8$ & $50 \cdot 75$ & $7 \cdot 25$ & $51 \cdot 9$ & 1,643 \\
\hline
\end{tabular}

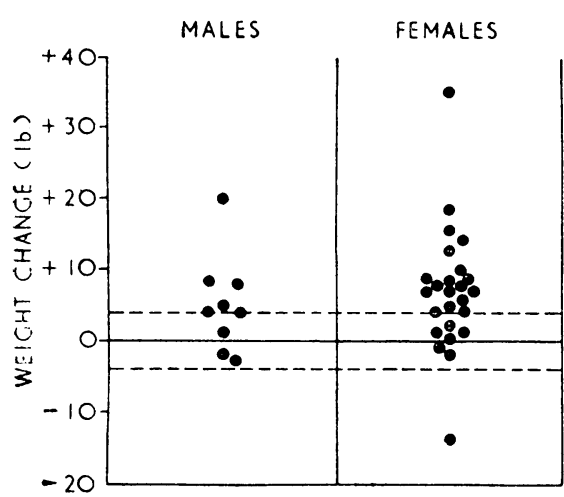

Fig. 4.-Weight change in patients after six months' institutional care.

\section{Report of Case of Megaloblastic Anaemia Due to Nutritional Deficiency of Folic Acid}

An 82-year-old spinster was first seen in May 1962 during the routine survey of new admissions to the local authority home. She had been living with her 84-year-old sister under very poor conditions, and admission to the home had been arranged at the request of the general practitioner. She was mentally confused and it was impossible to obtain an accurate dietary history, although the diet had consisted mainly of bread-and-butter, biscuits, and tea. She denied symptoms of any sort when first seen, and during the first few days of admission had a very poor appetite, and refused most of the cooked food offered to her. She was incontinent of urine and faeces. She was seen two days after admission and transferred to the Bristol Royal Infirmary.

On examination she was frail, with obvious malnutrition, anaemia, and senile purpura. There was marked papillary atrophy of the tongue. The nails were thin and flattened. Oedema of the ankles was present. There were no other abnormal physical findings.

Investigations.-Haemoglobin $30 \%$ (4.5 g./100 ml.) ; P.C.V. $14 \%$; M.C.H.C. $32 \%$. Blood film: the red cells showed anisocytosis with many macrocytes; the polymorphs showed a right shift, and platelets were scanty. Bone-marrow examination revealed fully developed megaloblastic changes. Serum iron $106 \mu \mathrm{g} . / 100 \mathrm{ml}$, serum vitamin $B_{12}$ (initial) $50 \mu$ g. $/ \mathrm{ml}$., serum folate $0.1 \mathrm{~m} \mu \mathrm{g} . / \mathrm{ml}$. Urinary excretion of Figlu $(+++)$. Jejunal biopsy normal. Dietary history: estimated daily intake of folic acid $20 \mu \mathrm{g}$.

Progress.-She was given physiological doses of folic acid $(50 \mu \mathrm{g} . /$ day). A reticulocyte peak of $15 \%$ was reached on the 12 th day of treatment. The haemoglobin level rose to $70 \%$ by the time she was discharged back to the local authority home. The serum level of vitamin $\mathrm{B}_{12}$ also rose to $160 \mu \mu \mathrm{g} . / \mathrm{ml}$. on the folic-acid therapy alone. As her deficiency of folic acid was gradually corrected she became less confused and also began to take the hospital diet with relish. When last seen, three months after her return to the home, she had gained a stone $(6.4 \mathrm{~kg}$.) in weight and was reported to be in good spirits and eating well.

\section{Discussion}

The combination of a low serum folate level and the excretion of increased amounts of urinary Figlu is good evidence of folic-acid deficiency, provided that vitamin- $\mathrm{B}_{12}$ deficiency can be excluded. In elderly patients folic-acid deficiency could be related to other factors apart from poor folic-acid intake. Drugs such as phenobarbitone (Hawkins and Meynell, 1958) are known to interfere with the action of folic-acid, and, more important still, neoplastic disease (Dymock, 1964) could cause deficiency due both to the anorexia associated with it and to the increased demands consequent on cellular proliferation. Sedative drugs had often been prescribed in our patients, though only $10 \%$ were taking barbiturates-the common sedatives being phenothiazines. Our practice of reviewing cases six months after their first attendance and discarding those who were deteriorating should have eliminated most oî those with neoplasia. It is also possible that the occasional patient could have had malabsorption, but this is rare in the elderly and likely to have been detected by clinical examination.

Allowing for these possibilities, it seemed that there was evidence of folic-acid deficiency, as judged by the serum folate level (serum level of folate $<6 \mathrm{~m} \mu \mathrm{g}$.) in $40(80 \%)$ of the 51 patients, and even if we exclude the six patients who were grossly anaemic the proportion with low levels is still $67 \%$. That this is an unduly high figure is suggested by the fact that the control elderly subjects, as judged by serum folate levels, also showed deficiency in 15 out of 51 subjects-that is, in $30 \%$ the levels were $<6 \mathrm{~m} \mu \mathrm{g} . / \mathrm{ml}$. This figure is in excess of that quoted for a series of normal patients in a younger age group, in whom $19 \%$ of females and $10 \%$ of males showed similar low figures (Gough et al., 1964). It is thus possible that the serum folate level normally falls with old age, a response perhaps to a normal fall in intake and possibly reduced demands consequent upon slower cellular activity. Equally it may mean 
that the normal control range quoted by Waters and Mollin (1961) is unduly high. The normal folate clearance might be cited in favour of this, though it is possible that it merely means that deficiency, though present, was not severe. Whatever the explanation, the difference between controls and patients is still statistically significant.

Very low folate levels $(<3 \mu \mathrm{g} . / \mathrm{ml}$.) were seen in nine patients and in none of the controls. The excretion of Figlu in excess amounts after histidine-loading is supporting evidence of deficiency, and this occurred in $31(62 \%)$ of 50 patients, though the relationship to the serum folate level was not a precise one. Four patients excreted Figlu with a normal serum folate level, but 25 others excreting Figlu had low folate levels. It is perhaps of interest at this point to note the frequent finding of a very low folate level $(<3 \mathrm{~m} \mu \mathrm{g} . / \mathrm{ml}$.) and increased Figlu excretion in patients with a normal haemoglobin and apparently normal red-cell morphology. In this range megaloblastic changes are normally seen. It is, however, possible that bone-marrow examination would have shown some evidence of megaloblastic erythropoiesis. Vitamin- $\mathrm{B}_{12}$ deficiency was not an important factor in producing evidence of folic-acid deficiency, as there were only two patients with pernicious anaemia in this group, both of whom were excluded, though five other patients had low vitamin- $B_{12}$ levels without megaloblastic change or anaemia.

It seems justifiable to attribute folic-acid deficiency in most of these patients to poor nutritional intake. Support for this comes from the poor diet that they were taking prior to admission. A significant dietary deficiency of folic acid, iron, protein, and total calories was present when compared with a similar group of control patients. Ascorbic acid intake was only significantly different in female patients, so that it is unlikely that this factor was a major one in determining the availability of folic acid in the tissues. A further factor in support of a dietary deficiency of folic acid and other substances comes from the beneficial effects of taking the diet available in the home, which was apparently of sufficient calorie and folic-acid content to reduce urinary Figlu excretion in 17 out of 23 patients, and to produce an increase in weight in a similar number.

The diet as supplied and calculated gives an adequate intake of calories for the generally low daily activities of an elderly patient in a supervised home. This allows for the fact that a reduction of $25 \%$ of intake below that for a young adult is assumed $(2,200$ and 1,800 calories a day are accepted as the energy requirements for ordinary living, excluding any form of work, of an adult male and female) (B.M.A. Report of the Committee on Nutrition, 1950). The dietary intake of protein and folic acid is also adequate, allowing for a similar reduction of intake in the elderly. The vitamin- $C$ allowance, according to calculations and without supplements, however, is probably only just sufficient, although the serum levels of some patients studied rose with the stay in the home. The dietary folate intake supplied did not cause a rise in the serum folate level. Nor presumably would it have been possible to increase serum folate levels on such a diet without supplements of folic acid. For example, a $25 \%$ increase in total dietary intake (which most elderly people would find excessive) would apparently have increased the intake of dietary folic acid by only about $12 \mu \mathrm{g}$.

A factor of importance not taken into account could be the varying availability of foodstuffs containing folic acid throughout the year. It is likely that serum folate levels vary according to dietary intake, and winter levels, when fresh green vegetables are not so freely available, may be considerably below those found in the summer months. This may have explained the failure of folic-acid levels to rise in some patients, because comparisons were made between admission levels during the summer and follow-up figures in the winter. A similar factor could explain the failure of vitamin-C levels to rise significantly in all patients studied. Foodstuffs con- taining folic acid are largely those which contain vitamin C, and megaloblastic anaemia responding to folic acid can occur in scurvy (Zalusky and Herbert, 1961). Vitamin-C levels were low in our patients, and levels rose, though not to normal values, after a six-month stay in the home.

If we accept malnutrition as the factor responsible for folicacid deficiency then the basic cause is simply the poor financial state, loneliness, apathy, and inability to obtain fresh vegetables because of infirmity so common in the elderly patient. Of these factors apathy seems of some importance, as it was striking how often elderly patients improvedstarting to eat and putting on weight-once the 'misery of living alone or in an unwanted atmosphere was left behind. Unfavourable comments are often made about homes run by municipal authorities, but many elderly patients are far better looked after than they had been before admission. Further, the home that we studied was a large one (total patients 560) -in fact, a modernized. "workhouse"-and it is likely that even better results could be obtained in the smaller municipal houses now being provided.

The implications of these studies are obvious. Everyone concerned with the welfare of elderly people is fully aware that attention to their plight is a most important and urgent matter. We have directed our investigations at only one facet of malnutrition in these patients-namely, folic-acid deficiencyand it is highly probable that other deficiencies exist, such as hypoproteinaemia and metabolic bone disease (Gough et al., 1964). The value of full clinical and haematological examination of all entrants to old people's homes is also clear, though the general practitioners responsible for care in this home would have found it impossible to deal with the extra work involved, since care of the inmates formed but a small part of their practices. Also, routine pathological investigations could not be made without reference to the hospital services. The problem is one of some magnitude, for there are 1,000 patients in homes for the elderly in Bristol alone.

\section{Conclusions}

It seems likely that regular vitamin supplements would be of value to the elderly person living alone. As regards folic acid, dosage should be in the "physiological" range (25-50 $\mu \mathrm{g}$./day) as otherwise precipitation of neuropathy in patients with vitamin- $B_{12}$ deficiency could occur. There were in fact two patients in our series with undiagnosed pernicious anaemia, and five others had low levels and could have been latent examples of the disease.

The difficulties to be met in trying to get the elderly subject to take vitamin supplements would be considerable (though easier in a municipal home, where the need for such therapy seems less). Though it may be questioned what harmful effects low levels of folate and increased values for Figlu excretion have, the fact that progression to severe megaloblastic anaemia can occur is well illustrated in Case 1; and, of course, many examples of nutritional deficiency of this type have been recorded in other groups of patients. It seems, however, that folate levels are a useful measure of malnutrition in subjects on a mixed animal and vegetable diet, as in this country, and serve to focus attention on generalized malnutrition, which, to some degree, is so common in many elderly patients.

\section{Summary}

Of 51 patients admitted to an old people's home and followed for six months folic-acid deficiency as judged by a low serum folate level was present in $40(80 \%)$ and in $34(67 \%)$ of those without severe anaemia $(\mathrm{Hb}<70 \%)$. Folate levels failed to rise with the diet provided, but Figlu excretion, previously increased in 31 of 50 patients ( $62 \%$ ), was returned to normal in 17 of 23 patients followed. Vitamin-C levels rose but not to normal, 
and all except 5 patients gained weight. The patients showed greater frequency of folic-acid deficiency than a group of aged control subjects, and their diets contained, prior to admission to the home, less folic acid, iron, protein, and total calories. The implications of these studies are discussed.

We are indebted to Professor R. C. Wofinden and Dr. J. F. Skone, of the Department of Public Health, for their help in arranging this investigation, and to the medical officers, Dr. J. Twomey, Dr. E. Bowles, and Dr. G. E. P. Lee, for allowing us to study patients under their care. We are particularly grateful to Sister R. A. Hill for her considerable help and to Mr. A. G. Smith for much administrative assistance. Miss E. Duncan (statistics) and Dr. A. Raper (haematology) gave valuable support.

This investigation was aided by a grant from the Research Committee of the United Bristol Hospitals.
REFERENCES

Butler, A. M., and Cushman, M. (1940). F. clin. Invest., 19, 459.

Chanarin, I., Mollin, D. L., and Anderson, B. B. (1958). Brit. F. Haemat., 4, 435 .

Dacie, J. V. (1956). Practical Haematology, 2nd ed. Churchill, London. Dymock, I. W. (1964). Lancet, 2, 114.

Forshaw, J., Moorhouse, E. H., and Harwood, L. (1964). Ibid., 1, 1004 Gough, K. R., Lloyd, O. C., and Wills, M. R. (1964). Ibid., 2, 1261. Read, A. E., McCarthy, C. F., and Waters, A. H. (1963). Quart. f. Med., 32, 243.

Hawkins, C. F., and Meynell, M. J. (1958). Ibid., 27, 45.

Kohn, J., Mollin, D. L., and Rosenbach, L. M. (1961). F. clin. Path., 14, 345.

McCance, R. A., and Widowson, E. M. (1960). Spec. Rep. Ser. med. Res. Coun. (Lond.), 297.

Roe, J. H., and Kuether, C. A. (1943). 7. biol. Chem., 147, 399.

Waters, A. H., and Mollin, D. L. (1961). F. clin. Path., 14, 335.

Zalusky, R., and Herbert, V. (1961). New Engl. F. Med., 265, 1033.

\title{
Physiological and Clinical Assessment of the Effect of the Musculotropic Agent Mebeverine on the Human Colon
}

\author{
A. M. CONNELL,* B.SC., M.R.C.P.ED.
}

Brit. med. F., 1965, 2, 848-851

It is possible to achieve smooth muscle spasmolysis by two methods which are pharmacologically distinct. Anticholinergic drugs, such as belladonna, act by blocking cholinergic fibres, while other preparations, such as papaverine, have a direct effect on smooth muscle. Anticholinergic preparations have been widely used as smooth-muscle relaxants. Success in this respect has been limited on account of their widespread effect through the organism. In order to achieve a therapeutic result at one site it is usually necessary to administer doses likely to produce effects elsewhere in the body, with resulting undesirable side-effects. On the other hand, a direct musculotropic drug such as papaverine does not have these effects (Goodman and Gilman, 1955). Unfortunately, papaverine has not been shown to be effective in the treatment of bowel disorders. Kralt et al. (1960) showed that in animals phenylethylamine derivatives of resperine had little or none of the central nervous effect of the parent compound but did have strong papaverine-like spasmolytic effects with less marked atropine-like effects. One of these compounds, Mebeverine, $\uparrow$ has been shown to have virtually no atropine-like action as tested by the lacrimation response, the sialogic response, and the inhibition of gastric secretion in cats. Dose for dose it was three times as potent as papaverine in inhibiting the peristaltic reflex of the guinea-pig ileum and 20 to 40 times more powerful in inhibiting the sphincter of Oddi (Lindner et al., 1963). The pharmacological properties of this compound have been extensively studied by Lindner et al. (1963), who have shown it to be remarkably free of untoward effects. In man no atropine-like effects could be established.

This paper assesses Mebeverine physiologically with regard to its affect on the motility of the colon and small intestine in man and clinically by a double-blind controlled trial of its effect on the irritable colon syndrome.

\section{Effect on Motility of Colon and Small Intestine in Man}

The patients were studied using either miniature balloons or a pressure-sensitive radio telemetering device of high sensitivity. The tubes were inserted into the colon through a sigmoidoscope, which was then withdrawn, and manœuvred until the miniature balloons lay at approximately 25,20 , and $15 \mathrm{~cm}$. from the anus respectively. Subsequently the patient was allowed to rest for at least 30 minutes before a recording was begun. Full details of the method and procedure have been described elsewhere (Connell, 1961). This method was used to study the pelvic colon.

The pressures in the small intestine and the proximal colon were studied, using a miniature ingestable radio transmitter whose frequency of oscillation is altered by external pressure. These changes are detected by an external aerial and receiver system and displayed on a suitable recorder (Connell and Rowlands, 1960). Full details of the technique and its application to the study of the small intestine and ascending colon have been described elsewhere (Connell et al., 1963).

\section{Subjects and Procedure}

The effect of Mebeverine on the sigmoid colon was studied during the course of routine motility studies in patients suffering from the irritable colon syndrome. In 10 patients Mebeverine was administered by a slow intravenous injection of $50 \mathrm{mg}$., and in one by an intramuscular injection of $75 \mathrm{mg}$. The effect of a slow intravenous injection of $50 \mathrm{mg}$. was tested in the small intestine (ileum) in two normal subjects and on the caecum in two subjects, one normal and one suffering from the Zollinger-Ellison syndrome. In all cases a basal recording lasting from 30 minutes to one hour was obtained, after which the patient received a control injection of intravenous saline. Thirty minutes later the Mebeverine was given and the recording continued for at least 30 minutes. Records were analysed over the 15-minute period following the control injection and the 15-minute perlod following the injection of Mebeverine. This analysis was made in respect of (1) the percentage of the term of analysis in which activity was present (percentage

\footnotetext{
* Institute of Clinical Science (Department of Surgery), Queen's University, Belfast. Lately Member of the Scientific Staff, Medical Research Council, Gastroenterology Research Unit, Central Middlesex Houncil,

† Not yet available in the United Kingdom, but is marketed in certain European countries.
} 